
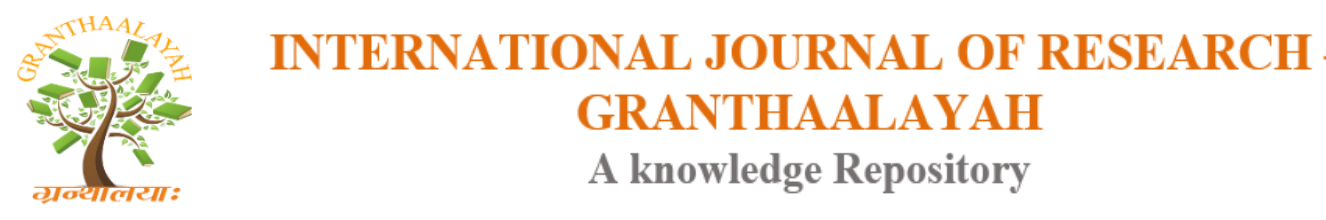

Management

\title{
IMPACT OF SOCIO ECONOMIC FACTORS INFLUENCE ONLINE SHOPPING
}

\author{
D.Melbha*1 \\ ${ }^{* 1}$ Research Scholar, Nesamony Memorial Christian College, Marthandam, Affiliated to \\ Manonmaniam Sundaranar University, Tirunelveli, 627012, Tamilnadu, India
}

\begin{abstract}
Since the internet has become a part and parcel of our existence, online shopping sites are burgeoning and getting popular with every passing day. Shopping, the definition and the concept, both have been revolutionized in the recent years. This is an inevitable part of progress, technically and socially. Presently social factors influence the online shopping. So I select this study, Impact of Socio Economic factors Influence online shopping. In this study I use 50 Private, public employees for data collection then this data collection purpose select Thiruvananthapuram city.
\end{abstract}

Keywords: Online Shopping; Consumer Behavior; Internet.

Cite This Article: D.Melbha. (2018). "IMPACT OF SOCIO ECONOMIC FACTORS INFLUENCE ONLINE SHOPPING.” International Journal of Research - Granthaalayah, 6(5), 326-333. https://doi.org/10.29121/granthaalayah.v6.i5.2018.1460.

\section{Introduction}

When you buy a product or a service over the internet, instead of going to a traditional brick-andmortar store, it is called online shopping. Globally, an increasing number of people are buying over the Internet because it is more convenient. You can purchase almost anything online starting with groceries and greeting cards to cell phones and ringtones for the cell phones, everything can be purchased online. While most people still find it convenient to buy their groceries from the neighbourhood shop, many people are purchasing rail and air tickets over the Internet. In addition, people and corporate as well, are also purchasing a variety of services online — such as a broking service or job search service.

\section{Methodology}

\subsection{Research Design}

The present study is a sample survey of selected respondents. The respondents were selected from Thiruvananthapuram city through selected Public Private employee. In this research questionnaire 
were analyzed and interpreted using simple percentage table for tabular analysis and formulated hypotheses so as to know more about the topic understudy.

\subsection{Primary Data}

The primary data for gathering the answers was an online questionnaire, which was sent to selected sample via email invitation. 50 respondents for data collections.

\subsection{Secondary Data}

Secondary resource provide initial insight into the research problem and include both raw data and published summaries, sources, such as, articles, books, journals, etc. In this research secondary data was mainly collected from Google Scholar website (http://scholar.google.com) which provides so many articles and researches.

\subsection{Tools For Analysis}

Percentage, hypothesis are used tools for data analysis

\section{Objectives of the Study}

1) To find out the Areas of living Influence online shopping.

2) To analysis the economic factors influence online shopping.

3) To study on social factors influence online shopping.

\section{Analysis of the Data}

\subsection{Gender wise classification}

Table 4.1:

\begin{tabular}{|l|l|l|l|}
\hline Sl.No & Gender & No of Respondent & Percentage \\
\hline 1 & Male & 30 & 60 \\
\hline 2 & Female & 20 & 40 \\
\hline & Total & 50 & 100 \\
\hline
\end{tabular}

The table no 4.1 exhibited that majority of the male respondents shopping online, secondly female respondents shopping online.

\subsection{Occupations}

Table 4.2:

\begin{tabular}{|l|l|l|l|}
\hline Sl.No & Occupation & No of the Respondents & Percentage \\
\hline 1 & Private Employee & 25 & 50 \\
\hline 2 & Public Employee & 25 & 50 \\
\hline & Total & 50 & 100 \\
\hline
\end{tabular}


The table No- 4.2 exhibited that $50 \%$ of the respondents are private employee then, $50 \%$ of the respondents are public employee.

\subsection{Education}

Table 4.3:

\begin{tabular}{|l|l|l|l|}
\hline Sl.No & Qualification of the Respondent & No of the Respondents & Percentage \\
\hline 1 & High School & 5 & 10 \\
\hline 2 & Secondary School & 8 & 16 \\
\hline 3 & Bachelor Degree & 15 & 30 \\
\hline 4 & Master Degree/MBA & 13 & 26 \\
\hline 5 & Above Master Degree & 9 & 18 \\
\hline & Total & 50 & 100 \\
\hline
\end{tabular}

The table no 4.3 shows that majority of the respondents Bachelor degree ie. $30 \%$, secondly ie $26 \%$ of master degree respondents shopping online, thirdly above master degree ie. $18 \%$, respondents shopping online, next secondary school ie. $16 \%$ respondents shopping online

\subsection{Age?}

Table 4.4:

\begin{tabular}{|l|l|l|l|}
\hline Sl.No & Age of Respondents & No of the Respondents & Percentage \\
\hline 1 & UUnder -18 & 3 & 6 \\
\hline 2 & $18-24$ & 14 & 28 \\
\hline 3 & $225-34$ & 16 & 32 \\
\hline 4 & $35-44$ & 7 & 14 \\
\hline 5 & AAbove -44 & 10 & 20 \\
\hline & Total & 50 & 100 \\
\hline
\end{tabular}

The table no 4.4 shows that majority of the respondents are age group of between $25-34$,secondly 18- 24 age of respondents using online shopping, next above- 44 age group of the respondents using online shopping, lastly under -18 age group of the respondents using online shopping.

\subsection{Area}

Table 4.5:

\begin{tabular}{|l|l|l|l|}
\hline Sl.No & Areas of the Respondents & No of the Respondents & Percentage \\
\hline 1 & Rural Area & 10 & 20 \\
\hline 2 & Urban Area & 25 & 50 \\
\hline 3 & Semi urban & 15 & 30 \\
\hline & Total & 50 & 100 \\
\hline
\end{tabular}

The Table No: 4.5 exhibited that majority of the respondents living in Urban areas, secondly living in Semi urban areas, lastly living in respondents Rural areas. 


\subsection{Methods of Online Shopping}

Table 4.6:

\begin{tabular}{|l|l|l|l|}
\hline Sl.No & Particulare & No of the Respondents & Percentage \\
\hline 1 & Own shopping & 7 & 14 \\
\hline 2 & with help of Spouse & 5 & 10 \\
\hline 3 & with help of children & 3 & 6 \\
\hline 4 & with help of mother & 4 & 8 \\
\hline 5 & with help of Father & 6 & 12 \\
\hline 6 & with help of brother/sister & 4 & 8 \\
\hline 7 & with help of Friends & 15 & 30 \\
\hline 8 & Others & 6 & 12 \\
\hline & Total & 50 & 100 \\
\hline
\end{tabular}

The Table no 4.6 shows that majority of respondents shopping online with help of friends ie $30 \%$, Secondly the respondents shopping online own ie 14\%, next the respondents shopping online with help of others and with help of Father ie.12\%, next the respondents shopping online with help of spouse, lastly the respondents shopping online with help of children.

\subsection{Cast}

Table 4.7:

\begin{tabular}{|l|l|l|l|}
\hline Sl.No & Particulars & No of Respondents & Percentage \\
\hline 1 & SC/ST & 10 & 20 \\
\hline 2 & Backward & 25 & 50 \\
\hline 3 & Forward & 15 & 30 \\
\hline & Total & 50 & 100 \\
\hline
\end{tabular}

The table no: 4.7 shows that majority of the responds backward category $50 \%$, Secondly respondents are forward category ie $30 \%$, lastly is SC/ST category of the respondent ie $20 \%$.

\subsection{House}

Table 4.8:

\begin{tabular}{|l|l|l|l|}
\hline Sl.No & Particulars & No of Respondents & Percentage \\
\hline 1 & Own house & 25 & 50 \\
\hline 2 & Rented & 15 & 30 \\
\hline 3 & Lease & 7 & 14 \\
\hline 4 & Other & 3 & 6 \\
\hline & Total & 50 & 100 \\
\hline
\end{tabular}

The table No 4.8 shows that majority of the respondents living in Own houses ie. 50\%, Secondly $30 \%$ of the respondent living in rented $6 \%$ houses, Thirdly $14 \%$ of the respondent living in Lease houses, lastly $6 \%$ of the respondents living in Other Places. 
4.9. Value of Your Wealth (current)

\subsection{Value of Your Wealth (current)}

Table 4. 9:

\begin{tabular}{|l|l|l|l|}
\hline Sl.No & Particulars & No of Respondents & Percentage \\
\hline & Below -1000000 & 3 & 6 \\
\hline & $1000001-2000000$ & 7 & 14 \\
\hline & $2000001-3000000$ & 12 & 24 \\
\hline & $3000001-4000000$ & 13 & 26 \\
\hline & Above -4000001 & 15 & 30 \\
\hline & Total & 50 & 100 \\
\hline
\end{tabular}

The table no:9 exhibited that majority of the ie $30 \%$ respondents value of the wealth is Above4000001 , next $26 \%$ of the respondents value of the wealth is $3000001-4000000$, next $24 \%$ of the respondents value of the wealth is $2000001-3000000$, next $14 \%$ of the respondents value of the wealth is 1000001-2000000, lastly 6\% of the respondents value of the wealth is Below - 1000000 .

4.10. Current Monthly Income (Present ie Absolute Value)

Table 4.10:

\begin{tabular}{|l|l|l|l|}
\hline Sl.No & Particulars & No of Respondents & Percentage \\
\hline & Below -10000 & 6 & $12 \%$ \\
\hline & $10001-20000$ & 7 & 14 \\
\hline & $20001-30000$ & 10 & 20 \\
\hline & $30001-40000$ & 12 & 22 \\
\hline & Above -40001 & 15 & 30 \\
\hline & Total & 50 & 100 \\
\hline
\end{tabular}

The table no $4: 10$ shows that 12\% respondents current monthly income Below-10000, 14\% respondents of the current monthly income 10001-20000, 20\% respondents of the current monthly income 20001-30000, 22\% respondents of the current monthly income 30001-40000, 30\% respondents of the current monthly income Above- 40001.

\subsection{Family Income}

Table 4.11:

\begin{tabular}{|l|l|l|l|}
\hline Sl.No & Particulars & No of Respondents & Percentage \\
\hline & Below -20000 & 6 & 12 \\
\hline & $20001-30000$ & 7 & 14 \\
\hline & $30001-40000$ & 11 & 22 \\
\hline & $40001-50000$ & 12 & 24 \\
\hline & Above -50001 & 14 & 28 \\
\hline & Total & 50 & 100 \\
\hline
\end{tabular}

The table no: 4. 11shows 12\% of the respondents Family income Below-20000, 14\% of the respondents family insome20001-30000, 22\% of the respondents family insome30001-40000, 
$24 \%$ of the respondents family income 40001-50000,28 \% of the respondents family income Above - 50001.

\subsection{Anybody Have Shopping Online in Your Family Members}

Table 4.12:

\begin{tabular}{|l|l|l|l|}
\hline Sl.No & Particulars & No of Respondents & Percentage \\
\hline 1 & Yes & 15 & 30 \\
\hline 2 & No & 35 & 70 \\
\hline & Total & 50 & 100 \\
\hline
\end{tabular}

The table no -4.12 shows that $30 \%$ of the respondents family members shopping online, $70 \%$ of the respondents family members not shopping online.

\subsection{In Which Age You Started Online Shopping?}

Table 4.13:

\begin{tabular}{|l|l|l|l|}
\hline Sl.No & Particulars & No of Respondents & Percentage \\
\hline 1 & Under 18 & 7 & 14 \\
\hline 2 & $18-24$ & 8 & 16 \\
\hline 3 & $25-34$ & 13 & 26 \\
\hline 4 & $35-44$ & 12 & 24 \\
\hline 5 & Above 44 & 10 & 20 \\
\hline & Total & 50 & 100 \\
\hline
\end{tabular}

The table no 4.13 exhibited that $14 \%$ of the respondents Under - 18 years starting online shopping, $16 \%$ of the respondents between 18-24 years starting online shopping, $26 \%$ of the between 25 34 years starting online shopping, 24\% of the respondents between 35-44 years starting online shopping, $20 \%$ of the respondents Above -44 years starting online shopping.

\subsection{How Many Years are You Stared Online Shopping?}

Table 4.14:

\begin{tabular}{|l|l|l|l|}
\hline Sl.No & Particulars & No of Respondents & Percentage \\
\hline 1 & Below - 1 Years & 17 & 34 \\
\hline 2 & 2 Years & 15 & 30 \\
\hline 3 & 3 Years & 11 & 22 \\
\hline 4 & Above - 3 Years & 7 & 14 \\
\hline & & 50 & 100 \\
\hline
\end{tabular}

The table No- 4.14 shows that $34 \%$ of the respondents Below - 1 year starting online shopping, $30 \%$ of the respondents 2 years starting online shopping, $22 \%$ of the respondents 3 years starting online shopping, $14 \%$ of the respondents Above -3 years starting online shopping. 


\section{Hypothesis}

1) There is no relationship between Area of living and online shopping since the computed value of (17.12) is greater than the tabulated value of (9.49), H0 (null) hypothesis shall be rejected This shows that Ares of living is influence the online shopping There is no relationship between Education and online shopping.

2) Since the computed value of (17.12) is greater than the tabulated value of (9.49), H0 (null) hypothesis shall be rejected this shows that Education is influence the online shopping. There is no relationship between Income level and online shopping.

3) Since the computed value of (17.12) is greater than the tabulated value of (9.49), H0 (null) hypothesis shall be rejected this shows that Income level is influence the online shopping. There is no relationship between Value of wealth and online shopping.

4) Since the computed value of (13.34) is less than the tabulated value of (15.5), H0 (null) hypothesis shall be accepted This shows that Value of the wealth is not influence the online shopping.

5) There is no relationship between Age and online shopping

Since the computed value of (12.45) is less than the tabulated value of (15.5), H0 (null) hypothesis shall be accepted this shows that Age is not influence the online shopping.

\section{Findings}

1) Majority of the male respondents shopping online

2) Majority of the respondents are private employee and Public.

3) Majority of the Bachelor degree Qualification Respondents shopping online

4) Majority of the respondents are age group of between $25-34$

5) Majority of the respondents living in Urban areas

6) Majority of respondents shopping online with help of friends

7) Majority of the responds backward category

8) Majority of the respondents living in Own houses

9) Majority of the ie $30 \%$ respondents value of the wealth is Above- 4000001 .

10) Majority of the respondent's current monthly income Above-40001

11) Majority of the respondents' Family income Above-50001.

12) Majority of the respondents' family members shopping online.

13) Majority of the respondents between 25 - 34 age group starting online shopping

14) Majority of the respondents Below - 1 year for starting online shopping

\section{Conclusion}

This study conclude that socio economic factors influencing online shopping ie education, Income level, Area of living etc. India is one of the nation for growth of online shopping. Improving socio economic factors and awareness of the individual is main reasons for growth for online shopping. Presently all transactions are cashless deals is also influence the growth online shopping. 


\section{References}

[1] Alam, S. S., Ali, M. Y., and Jani, M. F. M. (2011). AN EMPIRICAL STUDY OF FACTORS AFFECTING ELECTRONIC COMMERCE ADOPTION AMONG SMES IN MALAYSIA. Journal of Business Economics and Management, 12(2), 375-399.CrossRefGoogle Scholar

[2] Ayyagari, M., Demirguc-Kunt, A., and Maksimovic, V. (2011). SMALL VS. YOUNG FIRMS ACROSS THE WORLD, CONTRIBUTION TO EMPLOYMENT, JOB CREATION AND GROWTH (F. a. P. S. D. Team, Trans.) (pp. 41): The World Bank Development Research Group.

[3] Chiliya, N., Chikandiwa, C., Afolabi, B. (2011). FACTORS AFFECTING SMALL MICRO MEDIUM ENTERPRISES'(SMMES) ADOPTION OF E-COMMERCE IN THE EASTERN CAPE PROVINCE OF SOUTH AFRICA. International Journal of Business and Management, 6(10), 28-36.CrossRefGoogle Scholar

[4] Clarke R. (2005). THE PAST, PRESENT AND FUTURE OF B2C ECOMMERCE. STATEMENT FOR A PANEL SESSION, SYDNEY.http://www.rogerclarke.com/EC/B2C-0509.html

[5] Daniel, E., and Wilson, H. (2002). ADOPTION INTENTIONS AND BENEFITS REALISED: A STUDY OF E-COMMERCE IN UK SME. Journal of Small Business and Enterprise Development, 9(4), 331-348. doi:10.1108/14626000210450522.CrossRefGoogle Scholar

[6] Donny, B.U. (2014). Catatan Ringkas Tata Kelola and Praktik INTERNET INDONESIA. INDONESIA: ICT watch Indonesia.

[7] Drew, S. (2003). STRATEGIC USES OF E-COMMERCE BY SMES IN THE EAST OF ENGLAND. European Management Journal, 21(1), 79-88.CrossRefGoogle Scholar

[8] Dubelaar, C., Sohal, A., and Savic, V. (2005). BENEFITS, IMPEDIMENTS AND CRITICAL SUCCESS FACTORS IN B2C E-BUSINESS ADOPTION.Technovation, 25(11), 12511262.CrossRefGoogle Scholar

[9] Fricker, R. D., and Schonlau, M. (2002). ADVANTAGES AND DISADVANTAGES OF INTERNET RESEARCH SURVEYS: EVIDENCE FROM THE LITERATURE. Field Methods, 14(4), 347-367.CrossRefGoogle Scholar

[10] Gonçalves, R., Santos, S. S., and Morais, E. P. (2010). E-BUSINESS MATURITY AND INFORMATION TECHNOLOGY IN PORTUGUESE SMES.Communications of the IBIMA, 2010, 8.Google Scholar

[11] Govindaraju, R., Wiratmadja, I. I., and Rivana, R. (2015). ANALYSIS OF DRIVERS FOR ECOMMERCE ADOPTION BY SMES IN INDONESIA. Paper presented at the Interdisciplinary Behavior and Social Sciences: Proceedings of the International Congress on Interdisciplinary Behaviour and Social Sciences 2014.

[12] Jahanshahi, A. A., and Zhang, S. X. (2013). E-COMMERCE FOR SMES: EMPIRICAL INSIGHTS FROM THREE COUNTRIES. Journal of Small Business and Enterprise Development, 20(4), 849-865. doi:10.1108/JSBED-03-2012-0039.CrossRefGoogle Scholar

[13] Kartiwi, M., and T MacGregor, R. C. (2008). ELECTRONIC COMMERCE ADOPTION BARRIERS IN SMALL TO MEDIUM-SIZED ENTERPRISES (SMES) IN DEVELOPED AND DEVELOPING COUNTRIES: A CROSS-COUNTRY COMPARISON. Journal of Electronic Commerce in Organization, 5(3), 35-51.CrossRefGoogle Scholar

[14] Kotelnikov, V. (2007). SMALL AND MEDIUM ENTERPRISES AND ICT: ASIA-PACIFIC DEVELOPMENT INFORMATION PROGRAMME, e-Primers for the Information Economy, Society and Polity, (APCICT) 2007.

*Corresponding author.

E-mail address: Melbha25@ gmail.com 